\title{
Looking at Kazakhstan's Higher Education Landscape: From Transition to Transformation Between 1920 and 2015
}

\author{
Elise S. Ahn, John Dixon, and Larissa Chekmareva
}

In the past 25 years, Kazakhstan has undergone a period of rapid education reform. As it began transitioning from a Soviet Republic to an independent nation-state, President Nursultan Nazarbayev and the Kazakhstani government made it clear that the lynchpin to becoming a globally competitive market economy was education (Aitzhanova et al. 2014). Ideologically, this focus signified a watershed moment, as the philosophical underpinnings of Soviet higher education (HE) were uprooted, with the transition toward a market economy. However, this process of reforming Kazakhstan's HE system is situated amidst significant demographic, sociocultural and political shifts which have taken place in the last two decades.

E. S. Ahn $(\square)$

University of Wisconsin-Madison International Division, Madison, WI, USA

J. Dixon

Department of Political Science and Public Administration, Middle East

Technical University, Ankara, Turkey

L. Chekmareva

University of Massachusetts, Amherst, MA, USA

(C) The Author(s) 2018

199

J. Huisman et al. (eds.), 25 Years of Transformations of Higher

Education Systems in Post-Soviet Countries, Palgrave Studies in Global

Higher Education, https://doi.org/10.1007/978-3-319-52980-6_8 
Subsequently, while the path to education reform shares similarities to that of other states of the former Soviet Union (FSU), there are idiosyncrasies particular to the Kazakhstani context.

Starting with the establishment of its first HE institutions (HEI), this chapter provides a brief historical overview of HE in Kazakhstan starting from the Soviet period. The next section examines the education reforms that have been implemented since 1991 by examining three aspects of system transformation that the contributions in this edited volume are focusing on-horizontal diversification, vertical differentiation and interorganisational relationships (Teichler 1988). Drawing from various sources, such as archival Soviet documents, Kazakhstani MoES reports and policy papers, along with interviews with different Kazakhstani administrators and faculty members, we found that at the macro-level there have, in fact, been departures from the Soviet HE apparatus vis-à-vis regulatory reform. However, despite this, much change remains to be implemented in terms of institutional, pedagogical and research practices in order to fulfil the teaching, learning and research mission of HE. The chapter concludes with a discussion on ongoing and emerging challenges facing the Kazakhstani HE system, as well examining its Soviet HE legacy.

\section{The Foundations: Kazakhstan's Soviet Higher EDUCATION LEGACY}

The Soviet education apparatus began developing HE in the Kazakh SSR as part of its overall massification of education project in the 1920s and the emphasis on preparing local specialists during the korenizatsia period. Prior to this time, no HEIs existed in the territory of present-day Kazakhstan (Froumin et al. 2014; Kyzykeyeva and Oskolkova 2011). During the first phase of HE development starting in the 1920s, five institutions were established-Bukeev, Semipalatinsk, Kazakh, Orenberg Institutes of Public Education and the Kazakh Institute of Education in Alma-Ata (Dzholdasbekov and Kuznetsov 1975). Between 1927 and 1932, 15 more HEIs were established, expanding the focus to include medicine, agriculture and livestock, such as the Veterinary-Zoo Technical Institute (1928), Kazakh State Agricultural Institute (1930) and the Kazakh Medical Institute (1931).

The following 5-year period (1933-37) saw an expansion of pedagogical institutes throughout the Kazakh SSR, including the establishment of 
Kirov Kazakh State University (1934), as well as the inclusion of postgraduate (aspirantura) studies in different institutes (Dzholdasbekov and Kuznetsov 1975). Following World War II (1946-63), 16 more institutes were established in the Kazakh SSR, along with the Kazakh Academy of Sciences. ${ }^{1}$ In 1959, a state-level committee was formed to centralise the HE management within the Kazakh SSR, which would then eventually become the Kazakhstani MoES (Kyzykeyeva and Oskolkova 2011). By 1975, there were $47 \mathrm{HEIs,} \mathrm{which} \mathrm{offered} \mathrm{programmes} \mathrm{in} 175$ different areas for 200,000 students (Dzholdasbekov and Kuznetsov 1975). ${ }^{2}$

However, not only was the HE system undergoing transition during that time, but that was situated in the broader context of education reform. One of the early challenges facing HE was a bottleneck effect; because of limited access to quality primary and secondary education, access to $\mathrm{HE}$ was consequently limited. Moreover, as Kyzykeyeva and Oskolkova (2011) note, students' education trajectories were also affected by the rupturing of communities in the 1930s as a result of Stalin's social engineering strategy. Additionally, because HEIs expanded so rapidly between 1928 and 1975, they faced a number of pragmatic challenges including: classroom and student housing shortages, a lack of textbooks and various teaching materials and a shortage of qualified teaching faculty (Heynemann et al. 2007; Rumyantseva 2005; Silova 2011).

Like in the other SSRs, HE in the Kazakh SSR had several aims. The first was to produce specialists who could help sustain the Soviet Union's objectives, including education goals like universal literacy and sociopolitical ones like a commitment to the party ideology. Relatedly, the second aim was to reproduce specialists who would be able to work in industries that were being developed in various territories. For example, in the Kazakh SSR, this included the oil and gas sector (Froumin et al. 2014). In this way, the horizontal landscape of HEIs was an instantiation of these two pillars-ideological and industrial-and they were centrally determined in a command economy.

However, the high degree of specialisation also consequently resulted in resource inefficiency and knowledge compartmentalisation. This knowledge compartmentalisation was seen in the allocation of institutional functions - institutes focused on teaching or conducting applied research, and academies conducted more "pure" scientific research. ${ }^{3}$

By the end of the Soviet period, the Kazakh SSR had 55 HEIs that enrolled 287,400 students (NIIVO 1992). Table 8.1 provides an overview 
Table 8.1 Kazakhstani HEIs (AY1988-89)

\begin{tabular}{lcc}
\hline HEIs by academic focus & Quantity & Enrolled students \\
\hline Engineering & 12 & 80,989 \\
Transport & 2 & 7,153 \\
Agriculture & 7 & 40,455 \\
Economy/law & 3 & 18,452 \\
Education & 23 & 104,516 \\
Health, medicine, sport & 6 & 23,477 \\
Arts & 2 & 1,836 \\
Total & 55 & 276,878 \\
\hline
\end{tabular}

Source: Narodnoe Obrazovanie i Kultura v USSR (1989, p. 142, 202)

of the institutional specialisations that were inherited by the nascent Kazakhstani government.

While no official taxonomy is available regarding the types of institutions and the corresponding quantity, Table 8.2 provides a general taxonomy of the types of HEIs that the Kazakhstani MoES inherited.

Al Farabi Kazakh National University (originally Kirov Kazakh State University) is the oldest university in the country and was the only HEI that could be considered a "classical" university with its multiple Faculties and Departments and an enrolment of 12,909 students (1988) (MoskvaFinansy i Statistika Razdel 1989). Most of the other HEIs could be categorised as either regional institutes or specialised institutes that were subject to shared oversight by the MoES and another Ministry (e.g., the Ministry of Transport, Internal Affairs or Defense). Regional institutes were primarily defined by geographical distribution, for example, pedagogical institutes were established throughout the country. This is in contrast to specialised institutes which, as mentioned earlier, were sectorspecific-oil and gas, engineering and so on.

In sum, the Soviet HE legacy in the Kazakh SSR included: a system which was fundamentally undergirded by political ideology; isolation from international trends and practices, because of its ideological underpinnings; poor financing, which led to slow innovation; and systemically, the emphasis on specialisations, which were linked to the Soviet's raw economy (Rudista 2004). However, this legacy also included the network of 55 HEIs, of which the majority were engineering and pedagogy institutes, which provided the nascent Kazakhstani government a point of departure in 1991. 
Table 8.2 Types of Kazakhstani HEIs in AY1990-91

\begin{tabular}{|c|c|c|c|c|}
\hline $\begin{array}{l}\text { HEI type } \\
\text { (quantity) }\end{array}$ & Example & Location & Affiliation & Research activity \\
\hline $\begin{array}{l}\text { National } \\
\text { university (2) }\end{array}$ & $\begin{array}{l}\text { Al Farabi Kazakh } \\
\text { National University }\end{array}$ & Almaty & MoES & Pure \\
\hline $\begin{array}{l}\text { Regional } \\
\text { institutes (24) }\end{array}$ & $\begin{array}{l}\text { Kostanay Pedagogical } \\
\text { Institute }\end{array}$ & Kostanay & MoES & $\begin{array}{l}\text { Applied research/ } \\
\text { teaching only }\end{array}$ \\
\hline $\begin{array}{l}\text { Specialised } \\
\text { institutes (29) }\end{array}$ & $\begin{array}{l}\text { Kokshetau Technical } \\
\text { Institute of the } \\
\text { MoES Kazakhstan }\end{array}$ & Kokshetau & $\begin{array}{l}\text { Ministry of } \\
\text { Internal Affairs; } \\
\text { MoES }\end{array}$ & $\begin{array}{l}\text { Applied research/ } \\
\text { teaching only }\end{array}$ \\
\hline
\end{tabular}

Note:

${ }^{a}$ The other university in the Kazakh SSR was Karaganda State University as noted earlier. It should be noted that while Karaganda State University did have the status of university, it was smaller in terms of number of faculties and student enrolment in comparison to Al Farabi Kazakh National University.

bSee http://www.kti-tjm.kz/nash_instityt.html

\section{The Early Years: Higher Education Reform IN THE 1990s}

The dissolution of the Soviet Union brought about significant social, political and economic changes in Kazakhstan. Economically, from 1991 to 1996 the country's Gross Domestic Product dropped 39\%, resulting in an overall collapse of the country's economy (World Bank 2005). But despite seemingly grim prospects, the economy eventually began recovering around 1999 and by 2007, achieved an annual growth rate of 10\% and higher (Pomfret 2014). However, in spite of steady growth, Kazakhstan has not been exempt from the global economic downturn in the 2000s. Unsustainable levels of currency exchange rate control by the Kazakhstani Central Bank, combined with plummeting oil prices and economic sanctions on the Russian Federation starting in 2014, led to the dedollarisation of Kazakhstan's currency, the tenge, and floated the exchange rate. This resulted in three significant rounds of currency devaluation (2009, 2014 and 2015). Consequently, the inflation forecast for 2016 is now $7.9 \%$ with a predicted GDP growth of 3.3\% (Asian Development Bank n.d.).

Demographically, as the economy struggled, birth rates declined in the 1990s. This declining birth rate was reversed in the early 2000s, a shift which corresponds to the country's economic recovery and a period of relative sociopolitical stability as seen in Fig. 8.1. 


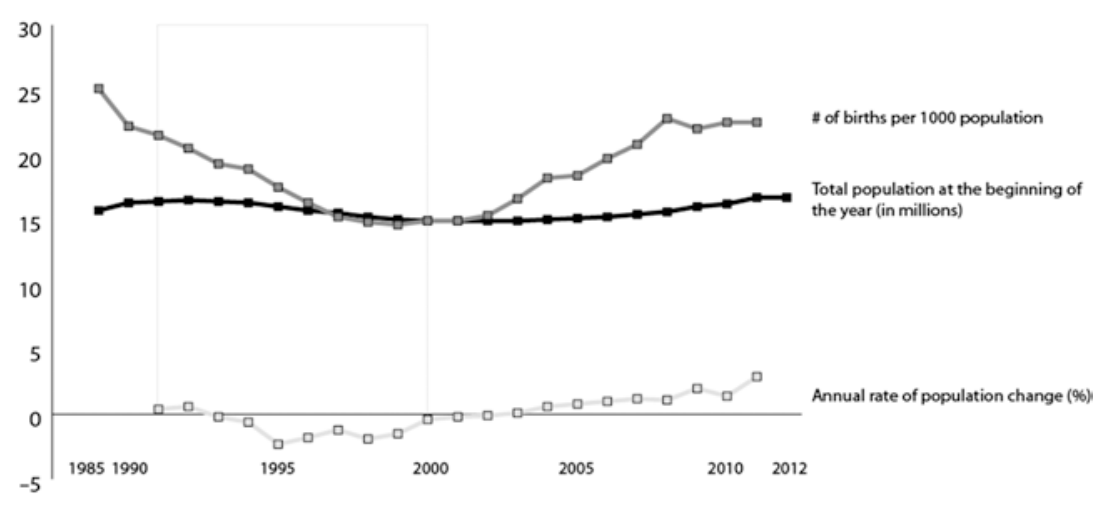

Fig. 8.1 Demographic trends (1985-2012) (Source: Adopted from the Agency of Statistics of the Republic of Kazakhstan (2013))

Socioculturally, with the establishment of its new Constitution in 1995, the Kazakhstani government began constructing a new civic identity. ${ }^{4}$ This began by privileging the titular Kazakh language as the official state language, moving toward the conflation of an ethnic Kazakh and Kazakhstani civic identity. ${ }^{5}$ This has resulted in changes in the language of instruction (LOI) in all schools - there was a shift in the LOI at the primary, secondary and tertiary level from Russian toward Kazakh (and more recently, the additional inclusion of English as the LOI).

In the 1990s, the Kazakhstani government began implementing a system-wide education reform amidst wide-scale sociopolitical-cultural reforms. The government's focus at the time was primarily on creating a regulatory structure that could create the conditions under which education reform could take place. The Constitution (1995) established the right to compulsory education for all Kazakhstani citizens, the Law on Education (1992) and the Law on Higher Education (1993), ${ }^{6}$ along with other regulations and standards (Yakavets 2014). What did not change immediately was who "owned" education-HE remained a state-owned enterprise. Consequently, this meant that the government maintained the all-encompassing centralised control that had existed under the Soviet regime (Sarinzhipov 2013).

Figure 8.2 provides an overview of the main foci of the regulations initiated between 1991 and 2015 . 


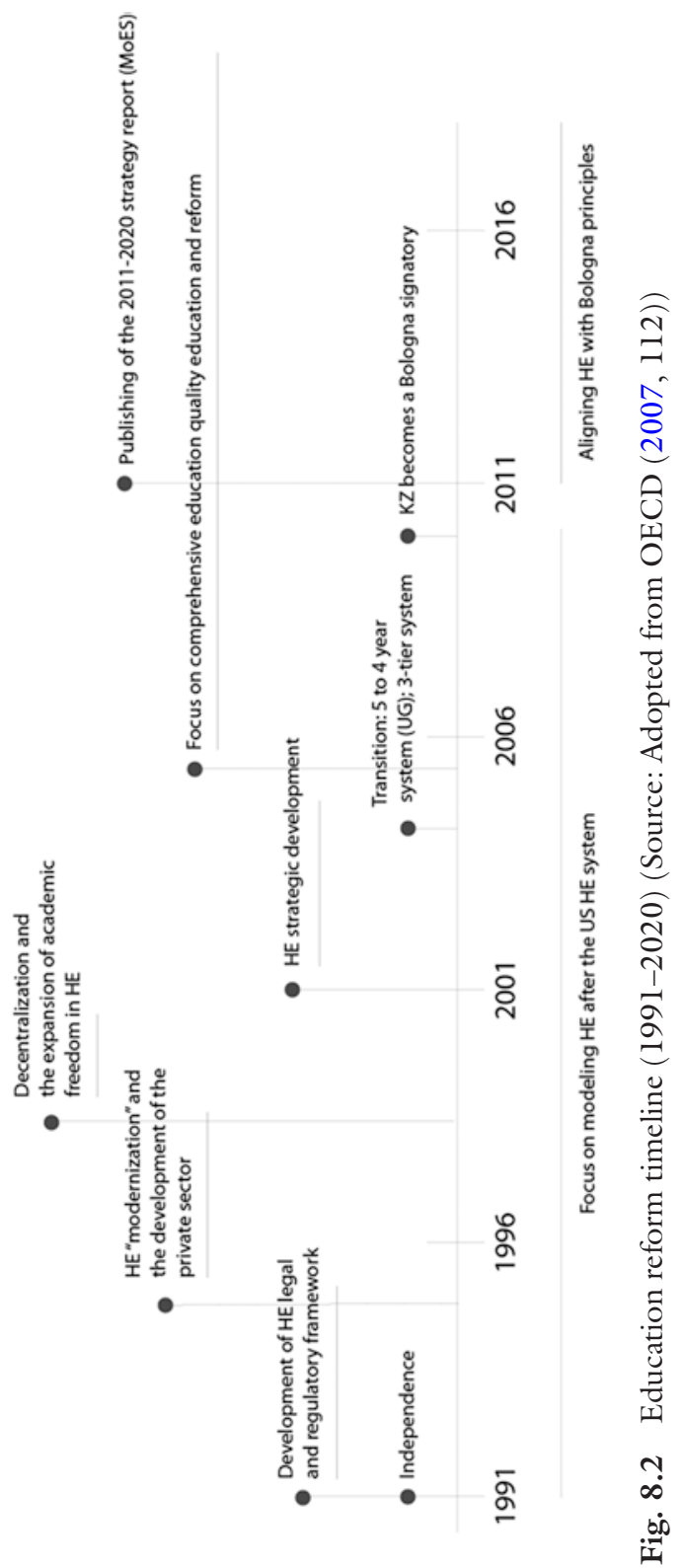


Although there were a number of departures from the Soviet HE system and orientation in the new legislation and regulations, the most significant was the opening of private HEIs. The 1993 legislation "On Higher Education" permitted private universities to operate in Kazakhstan (albeit under the auspices of all MoES regulations). ${ }^{7}$ During AY1990-91, there were 55 public HEIs. After the 1993 law was passed, 32 more HEIs opened, the majority of which were private (Sulima 2008). By AY1996-97, $43.2 \%$ of the HEIs were public and $56.8 \%$ were private (OECD 2007)this distribution stayed similar through AY2013-14 (MoES 2014). The distribution of students enrolled in public and private HEIs was also similar (although there was some fluctuation). For example, in AY2012-13, $49.1 \%$ of students were enrolled in public HEIs. By AY2014-15, this percentage shifted, with $48.3 \%$ of students enrolled in public HEIs and $50.3 \%$ enrolled in private HEIs (MoES 2015). So while the proliferation of private HEIs was initially permitted through the enabling of regulatory reform, as seen in the enrolment distribution, there was a corresponding demand by Kazakhstanis who felt that acquiring a HE degree was essential to being employed in the new economic world order as demonstrated in Fig. 8.3.

Figure 8.3 reveals that the patterns of growth in student enrolment and the number of HEIs are similar. There are upward trends in both graphs with a particular peak in between AY2004-07. However, since then, there has been a decline in both the number of HEIs and enrolment due to increased accountability from the MoES (HEI decline) and demographic decrease (student enrolment). But despite these social and institutional shifts, the opening of HE to the private sector helped absorb the demand for HE particularly in the first 15 years of the Republic.

With an increased HE demand and the establishment of 114 HEIs in the 1990s, it is plausible to expect that geographical access to HE would have increased. This, however, did not happen. During the Soviet period, HEIs were primarily located in major urban areas (e.g., Almaty, previously Alma-Ata) or in oblasts with particular raw material factories (e.g., East Kazakhstan). However, when looking at the distribution of HEIs in the 1990s, the majority were established in Almaty city because it was previously the capital of the Kazakh SSR and for the first few years of independent Kazakhstan. Figure 8.4 shows that although Almaty is no longer the capital, it still has the highest proportion of HEIs in the country. 


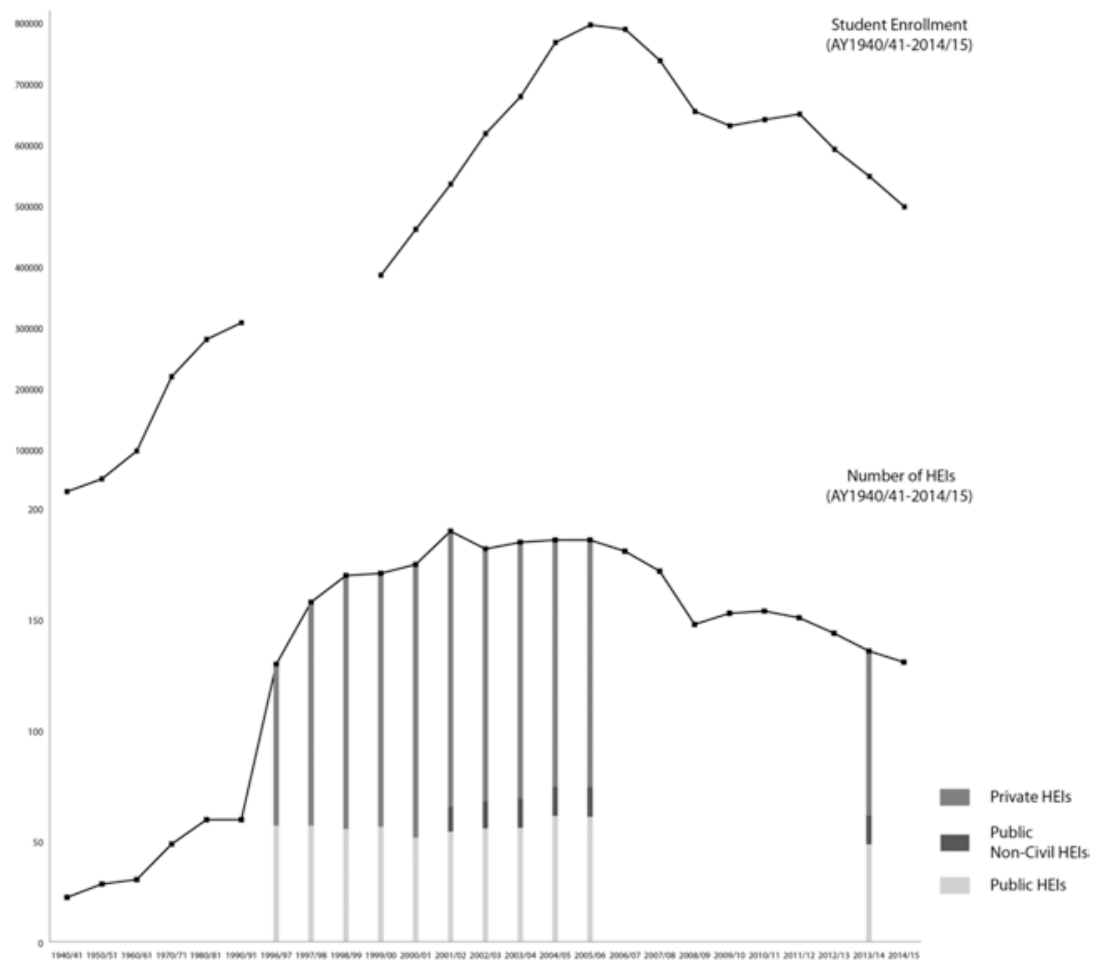

Fig. 8.3 HEI trends over time by institutions 1940-2014 (Sources: Adopted from Brunner and Tillett (n.d.); MoES (2014, 2015); Ministry of Economics (2015); Moskva-Finansy i Statistika [Moscow Finance and Statistics] $(1989,202)$; $\operatorname{OECD}(2007,40)$; Zhakenov (n.d.))

Thus, in terms of the horizontal institutional diversification of HE after independence, although it remained completely under the auspices of the government through the MoES under the Law "On Education" (1993, 1997), the 1993 law did initially facilitate the establishment of private universities. This helped introduce financial diversity into the previously solely, state-funded sector. In turn, the proliferation of new private HEIs, along with the creation of new universities as a result of merging different institutes, helped to absorb the mass demand for HE. 


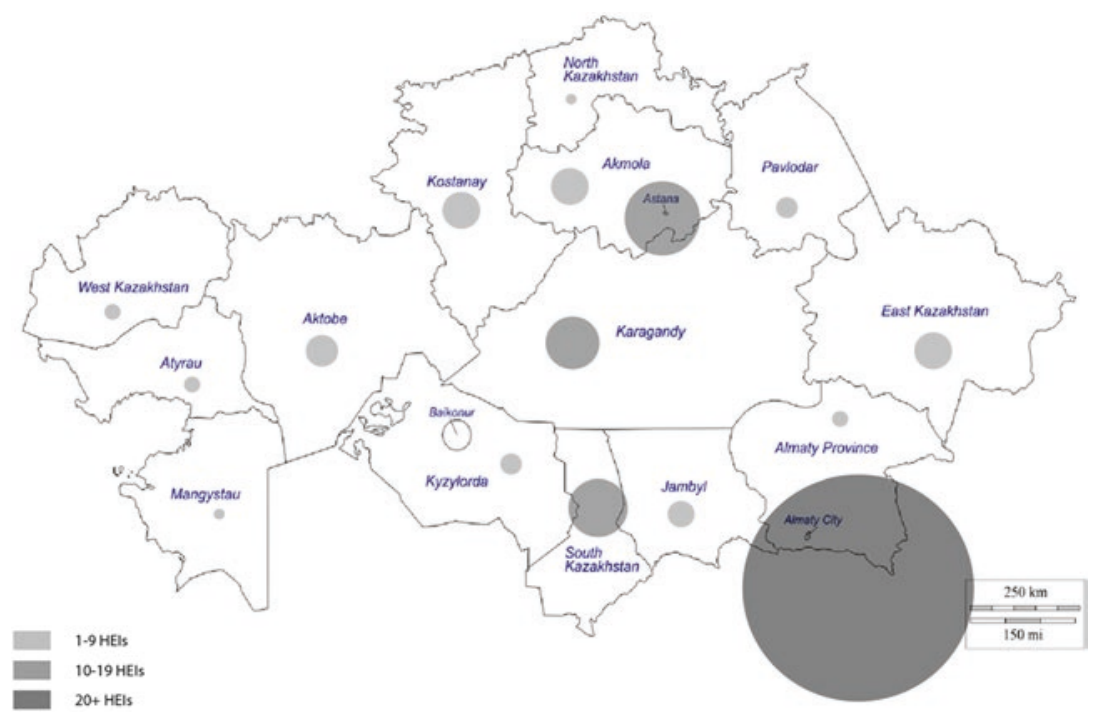

Fig. 8.4 Distribution of universities in Kazakhstan in AY2014-15 (Source: MoES (2015))

\section{The Privatisation of HE and the Modernisation OF HE: The 2000s}

While the 1990s introduced private HEIs into the system, the year 2000 began the process of privatising public HEIs. The general privatisation process of state-owned enterprises initiated in the 1990s was then extended to select HEIs with the passing of the law "On the List of the Republican State Enterprises and Institutions to be Privatised in 2000-01". The result was that 12 public HEIs became joint-stock companies (JSCs) ${ }^{8}$ - a scheme where the Kazakhstani government shares ownership with other shareholders, which could be a private individual(s) or corporation. The privatisation of HEIs was (and continues to be) an attempt to diversification of the funding of higher education by introducing new revenue streams (including student tuition fees). Consequently, the privatisation of HEIs continued the process of horizontal $\mathrm{HE}$ diversification.

At that time, eight universities were given the status of "National University"-Al-Farabi Kazakh National University, Gumilyov Eurasian 
National University, Kazakh National Agrarian University, K.I. Satpayev Kazakh National Technical University, S.D. Asfendiyarov Kazakh National Medical University, T.K. Zhurgenov Kazakh National Academy of Arts, Kurmangazy Kazakh National Conservatory and the Kazakh National University of Arts.

Thus, after diversifying the Kazakhstani HE horizontal institutional landscape with the inclusion of the private sector, the MoES then moved toward creating greater vertical differentiation. Generally, the type of HEI is determined by the institution's licencing, which is based mainly on the number of faculties that institution has-HEIs with three or more faculties can apply to become a university, while those with less than three are designated as an institute. An academy was a HEI that usually had one specialisation (e.g., the Academy of Civil Aviation). However, there are further distinctions which can be made via special Presidential Orders as seen above since the aforementioned Order granted eight universities the status of "National University". National universities are public HEIs that teach a wide gamut of programmes that have made a contribution to $\mathrm{HE}$ in the country.

Subsequently, 18 HEIs were established as regional centres of teaching learning (Zhankenov n.d.). These were also categorised as "state universities". Many of these regional or state universities were institutes that were merged in the 1990s in order to provide a diversity of taught program offerings and ultimately to attract more students. Table 8.3 is an overarching taxonomy of HEI types based on institutional mandate and scope and does not include all the different ways Kazakhstani HEIs are classified.

As the MoES continues with institutional privatisation and by extension, with the move toward a free market HE environment, it requires all HEIs to collect a percentage of the student fees which varies by institution in order to prepare them for eventual financial independence. Other policies and practices have been introduced to create an even "playing field" and to increase inter-institutional competition.

A significant part of increasing competition in the HE sector was the need to create a more transparent student admissions process (for both students and HEIs). In the 1990s, Kazakhstani HEIs were initially allowed to admit students based on their academic background and performance and how that fits with an institution's specialisation. In 2001, a new quality assurance system was implemented by the MoES, resulting in the establishment of the Committee for Supervision and Attestation; the National 
Table 8.3 HEIs by type based on the law "On Education" (2007)

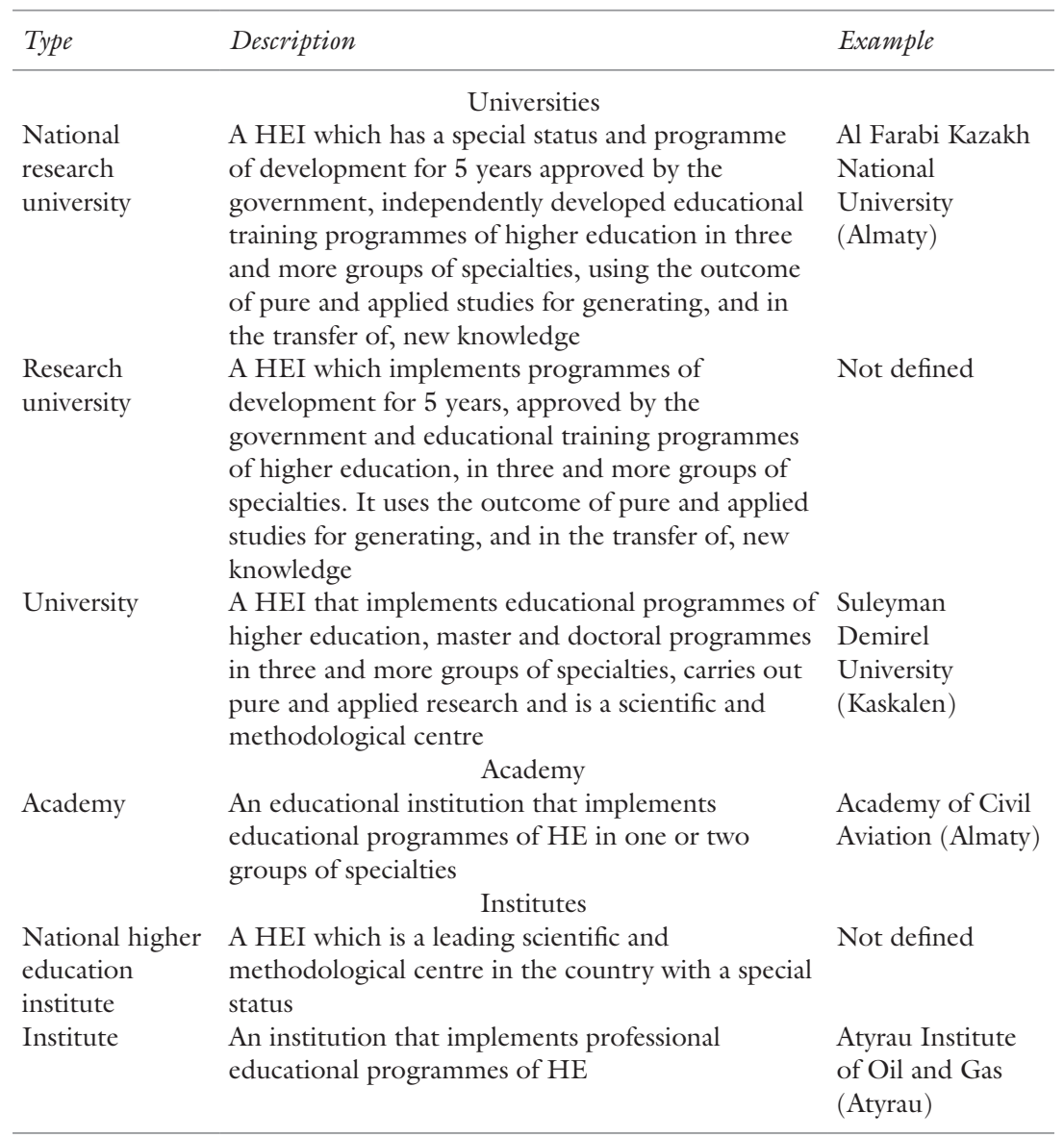

Source: Law “On Education” (2007); National Tempus Office (2012)

Centre for Educational Quality Assessment; the National Accreditation Centre; the Centre for Certification, Quality Management and Consulting; and the National Centre of State Standards for Education and Tests (OECD 2007). To combat public perceptions regarding corruption linked to university admission, the Unified National Test (UNT) (Edinoe 
Nacional'noe Testirovanie) - a 3-hour university entrance test and also an upper secondary school completion assessment-was developed for AY2003-04. ${ }^{9}$ High scorers on the UNT would be guaranteed admittance to a public university and could receive a full scholarship via state grants. An alternative test - the Comprehensive Test (CT) - was later developed for students who attended: a non-Kazakh/non-Russian language of instruction secondary school, a school abroad but wanted to attend a Kazakhstani university or a vocational/technical secondary school but decided to enter university.

However, while the establishment of these tests addressed issues regarding the perceived corruption connected to university entrance by providing a more standardised measure of academic ability, there remain some unresolved issues. Neither test was or is calibrated to international university entrance standards. Consequently, students who take the UNT or the CT cannot use the scores earned toward admission into universities outside of Kazakhstan. From an assessment standpoint, they have been criticised because of their lack of subject matter depth due to the limits of the current format-30 multiple choice questions per section in 5 subject areas with an emphasis on language. ${ }^{10}$

A student's performance on the UNT not only has implications for their $\mathrm{HE}$ admission but also to whether students qualify for a government scholarship. These scholarships are "portable", which means that grant recipients have some choice(s) regarding which HEI they wanted to attend (EC 2010). But the government's priority areas for education and economic development, nationality and language of education determine grant availability. The other factor that is taken into consideration is membership of population categories that are under-represented in the $\mathrm{HE}$ student population, which include orphans, students from single-parent homes or from rural communities and young people with disabilities (EC 2010). The MoES also awards other types of scholarships for exceptionally high-achieving students (e.g., Presidential Scholarships). The MoES (2010) also established the "State Education Savings System", whereby parents can save money for their children's HE costs by providing a premium return on their savings. Note, however, HEIs can also provide different funding support to better attract students including institution-specific financial aid and loans, scholarships for high-achieving students and tuition and fee waivers or discounts. 
Systemically, in AY2004-05, the Kazakhstani HE system changed from the 5-year Soviet-era bachelor degree to a 4-year degree. This was intended to facilitate increased student and faculty mobility in and out of Kazakhstan, as well as greater degree of recognition in alignment with international institutional structures (Piven and Pak 2006). This paved the way for discussions regarding the possibility of Kazakhstan joining the European Higher Education Area (EHEA). On 12 March 2010, Kazakhstan then became the first Central Asia Republic to sign the Lisbon Convention of the Bologna Process (BP) becoming its 47th signatory (Kazinform 2010).

Joining the BP has had the most comprehensive impact on the Kazakhstani HE system. Soon after joining the BP, the "State Programme of Education Development in the RoK for 2011-2020" was passed (MoES 2010). This outlined the government's plan to align all three tiers of education to international standards by the year 2020 in order to achieve its stated goal of "increasing [the] competitiveness of education and [the] development of human capital through ensuring access to quality education for sustainable economic growth" (MoES 2010, 1). The plan was comprehensive, covering everything from financing to the professional development of teacher faculty, along with intended structural and programme changes. The HE focus of this report was on re-aligning its structural, university governance and autonomy reforms to conform to BP priorities. In addition to legislation that was passed in the 1990s, the Law "On Education" (2007) and the Law "On Science" (2011) provided the legal framework that has been guiding $\mathrm{HE}$ reform.

In addition to system reform, one of the goals outlined in the MoES plan (2010) was the need to increase institutional and research output to meet international standards. In order to fund and support research, a number of laws have been passed, including the Law "On Science" (2001), Law “On Innovative Activities" (2003), Patent Law (2003) and the Law "On Support of Innovative Activities" (2006). In 2003, less than 100 articles were published per 10,000 researchers (Thomson n.d.; OECD 2007). The MoES (2010) stated that the goal was to have $2 \%$ of faculty members publish in international, peer-reviewed journals by 2015 and $5 \%$ by 2020 . But according to MoES (2014), out of 41,636 
faculty members, $541(1.3 \%)$ have publications in international (peerreviewed) journals. In terms of gender parity, there is an almost equal representation of genders among researchers, with the majority of researchers are in the STEM fields-Science, Technology, Engineering and Mathematics (UIS n.d.). However, in terms of researchers by sector, the $\mathrm{HE}$ and non-profit sectors have seen a gradual increase between 2005 and 2011 with a decrease in number of researchers in the governmental agencies (UIS n.d.).

The government remains the largest funder of research and development; it is responsible for between 25\% (2011) and 61.5\% (2003) of all related expenditures (UIS n.d.), which has limited the growth of research and development in HE. After independence, similar to the other postSoviet countries, the Kazakhstani HE system faced a physically crumbling research infrastructure, in terms of laboratory space, equipment, resource centres and libraries, further constraining the ability of researchers to conduct research (MoES 2010). This is not surprising, given the reduction in the expenditure on research and development since 2003 (UIS n.d.). Relatedly, another systemic constraint on research output is the MoES's constrained funding priorities and by extension research outputs (OECD 2007). However, partnerships between international organisations like the British Council and individual universities (e.g., Al Farabi Kazakhstan National University), are moves to diversify research funding and have contributed to building deeper research capacity of Kazakhstani academics.

Another impetus for Kazakhstan joining the EHEA and committing to the implementation of BP was the internationalisation of HE through faculty and student mobility through programmes like ERASMUS MUNDUS. Systemically, this meant that HEIs would need to adopt the European Credit Transfer and Accumulation System (ECTS) and provide Diploma Supplements in order to facilitate mobility. ${ }^{11}$ Moreover, in 1998, Kazakhstan signed an agreement between Belarus, Kyrgyzstan and Russia allowing for degree equivalence recognition, thereby increasing opportunities for student and graduate mobility between the four countries (Poletaev and Rakisheva 2011). Additionally, according to MoES (2010), as of 2010, over 20,000 Kazakhstani students had studied abroad, of whom 3000 were Bolashak scholarship holders. ${ }^{12}$ In terms 
of in-bound student mobility, Kazakhstan is the second most popular destination to study in Central Asia (behind Russia) (Brunner and Tillet n.d.).

In terms of creating a more transparent system, MoES (2010) articulated a set of relevant HE policy aspirations-to establish a board of trustees at different HEIs to help provide stakeholder-informed governance, to continue the professionalisation of academic administrators (through various training programmes) and to institute a transparent rectorappointment system. ${ }^{13}$ To support academic administrators, the MoES stated its intention of creating a comprehensive and easily accessible database of educational statistics, which would be made available to all universities to facilitate data-informed management decisions. While a database is not yet available, the MoES has been making yearly reports of aggregated HE data available on its website. ${ }^{14}$ Also integral to the process of transforming $\mathrm{HE}$ provision is the development and implementation of lifelong learning through professional development opportunities for university administrators and leaders. Such training opportunities are being conducted through institutions like Nazarbayev University and KIMEP University.

Along the same vein of transparency, the proliferation of HEIs in the 1990s and 2000s is now being curbed by the emphasis on institutional quality assurance. At its peak, there were 182 HEIs in the system (2001) but by AY2015-16, there were 126 (MoES 2015). In 2011, the Independent Agency for Accreditation Rating (IAAR) was established as an independent national agency with a remit that includes the ranking of HEIs, the improving of their competitiveness, and their institutional and specialised accreditation. The Independent Quality Assurance Agency of Kazakhstan (IQAA) was established in 2012, also an independent national agency but with a remit to provide both institutional and programme accreditation for Kazakhstani HEIs. Out of the 131 universities in AY2014-15, only 3 universities (2\%) had received institutional accreditation from the IAAR (www.iaar.kz), 4 (3\%) from IQAA (www.iqaa.kz) and only 1 had all of its degree programmes accredited by an agency listed on the European Quality Assurance Register. ${ }^{15}$

While joining the BP has increased discussions regarding what constitutes "quality education", it has also foregrounded a number of policy 
tensions which were created in the first 20 years of education reform. One example of this is the tension between the MoES' centralised control over a significant portion of institutional operations and discourses on decentralisation and privatisation. Because one of the pillars of the BP is institutional autonomy, HEIs need to be given more procedural and substantive autonomy. "Procedural autonomy" refers to the ability for universities to make decisions related to higher-level administrative processes. "Substantive autonomy" refers to the ability to make decisions related to academic affairs. The later would include what degree programmes universities wanted to offer students and, subsequently, the curricular requirements (Soltys 2014). According to MoES (2010), it was intended that HEIs would be granted autonomy gradually-national research universities in 2015, national HEIs in 2016 and the rest by 2018. To date, this has not been the case; the exception is Nazarbayev University, which was established from its inception as an autonomous HEI by Presidential Order. ${ }^{16}$

Currently, the reach of the MoES still includes the types of degree programmes HEIs can offer through the list of state classifiers-HEIs cannot innovate degrees or programme titles which are not listed in the list of 342 state classifiers (OECD 2007; Sulima 2008), the standardisation of programme courses and core course curriculum through the State Compulsory Education Standards, the standardisation of faculty promotion and, for public HEIs, the constraints on tuition rates for feepaying students. According to Sarinzhipov (2013), regardless of whether a HEI is public or private, they all need to comply with the MoES requirements regarding these aforementioned areas in order to maintain their institutional licences.

The centralised control of the MoES also affects research output. While academics need to conduct research and publish in order to receive promotion (according to the same criteria used pre-1991), there remain serious constraints on their time because of heavy teaching expectations, so faculty research output remains relatively low. Such constraints include 800-900 contact hours with students per academic year, mandatory office hours, thesis supervision, student consultations as well as being available for a variety of different activities related to university service, which are prescribed in various education laws. This, combined with low academic salaries and institutional corruption, has resulted in the phenomenon of 
faculty teaching at multiple universities - further limiting their time and their personal capacity to conduct original, independent research (Silova and Steiner-Khamsi 2008).

However, if the MoES does begin granting both substantive and procedural autonomy to HEIs, this would significantly change the dynamics between HEIs. Students would more freely be able to choose between meaningfully different programmes of study, educational experiences and curricula, and HEIs would have the ability to potentially innovate and engage directly with industry to produce graduates who would be able to aptly participate in the labour market.

Table 8.4 attempts to provide a comprehensive overview of the different categories that were created by the MoES to delineate and differentiate (horizontally and vertically) the emerging HE landscape between 1993 and 2010.

For potential students, such categories are important because they determine whether their choice of $\mathrm{HE}$ is an eligible host for a government scholarship, as well as the quality of education they might receive. But for university rectors and administrators, the categories presented in Tables 8.3 and 8.4 are marginally flexible. Private HEIs can move from being institutes to universities, but by virtue of being private, they currently cannot become national institutions. Because public HEIs are under the auspices of the MoES, there is little major institutional/structural changes which can be initiated by the institutions themselves. The table corresponding to this chapter in the Appendices provides an overview of the total number of HEIs that fit into the categories outlined in Table 8.4 as of AY2014-15.

In addition to the vertical and horizontal institutional distinctions that the MoES has made, it has also created another institutional taxonomy which highlights the university's expected research output based on the official institutional licence it has been granted. This research distinction was based on the Law "On Education" (2007). Logistically, public HEIs can be given the special status of "National University" or "National Higher Education Institute" by means of a Presidential Order. "Research University" is a title which is ostensibly open for both public and private HEIs under the auspices of the Law "On Education" (2007). However, it is noteworthy that to date, no HEI has been officially granted this status. 
Table 8.4 The Kazakhstani HE landscape between 1993 and 2010

\begin{tabular}{|c|c|c|c|c|c|}
\hline Type & Vertical & Licensing & Research & Example & Location \\
\hline \multirow[t]{4}{*}{ International } & International & University & & Yasawi & Turkestan \\
\hline & & & & International & \\
\hline & & & & Kazakh-Turkish & \\
\hline & & & & University $^{\mathrm{a}}$ & \\
\hline \multirow[t]{9}{*}{ Public } & Autonomous & University & $\mathrm{x}$ & Nazarbayev University & Astana \\
\hline & National & & & Al Farabi Kazakh & Almaty \\
\hline & & & & National University & \\
\hline & & Institute & & & \\
\hline & & Academy & & Academy of Public & Astana \\
\hline & & & & $\begin{array}{l}\text { Administration } \\
\text { under the President } \\
\text { of the Republic of } \\
\text { Kazakhstan }\end{array}$ & \\
\hline & State & University & & & \\
\hline & & Institute & & $\begin{array}{l}\text { Atyrau Institute of } \\
\text { Oil and Gas }\end{array}$ & Atyrau \\
\hline & & Academy & & & \\
\hline \multirow[t]{3}{*}{ Private: JSC } & & University & & KIMEP University & Almaty \\
\hline & & Institute & & & \\
\hline & & Academy & & $\begin{array}{l}\text { Academy of Civil } \\
\text { Aviation }\end{array}$ & Almaty \\
\hline \multirow[t]{7}{*}{ Private } & & University & & $\begin{array}{l}\text { Almaty Management } \\
\text { University }\end{array}$ & Almaty \\
\hline & & Institute & & Eurasian & Astana \\
\hline & & & & Humanitarian & \\
\hline & & & & Institute & \\
\hline & & Academy & & Kazakh Academy of & Almaty \\
\hline & & & & Labor and Social & \\
\hline & & & & Relations & \\
\hline
\end{tabular}

${ }^{a}$ Yasawi International Kazakh-Turkish University is unique because it is a joint education endeavour by the Kazakhstani and Turkish governments.

By default, then, all other HEIs fall under the conventional categories of "university", "academy" or "institute" with no official distinguishing descriptor. Table 8.5 provides an overview of the types of HEIs, profiles of exemplars and what they define as demonstrations of research in their institutional contexts. 


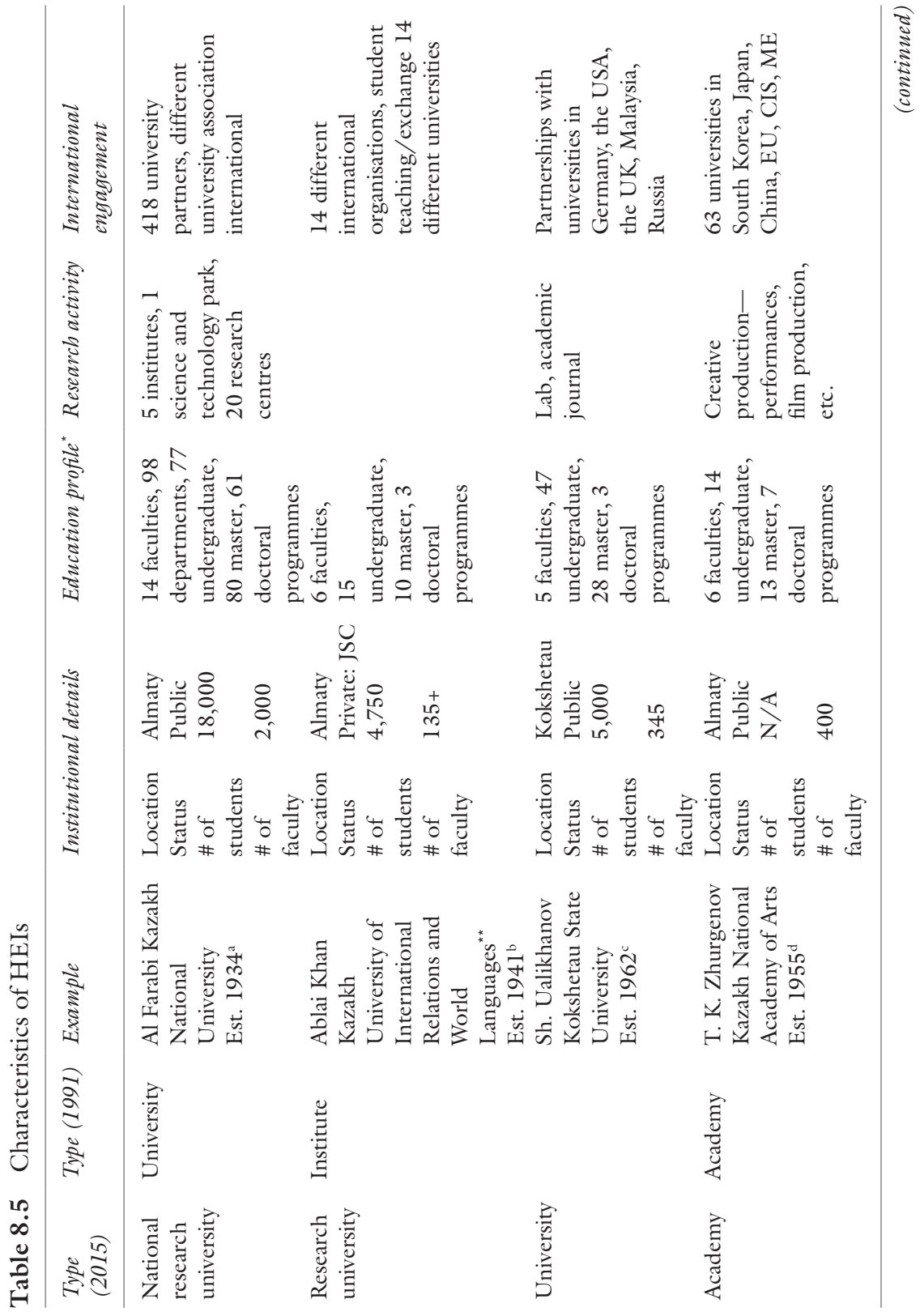




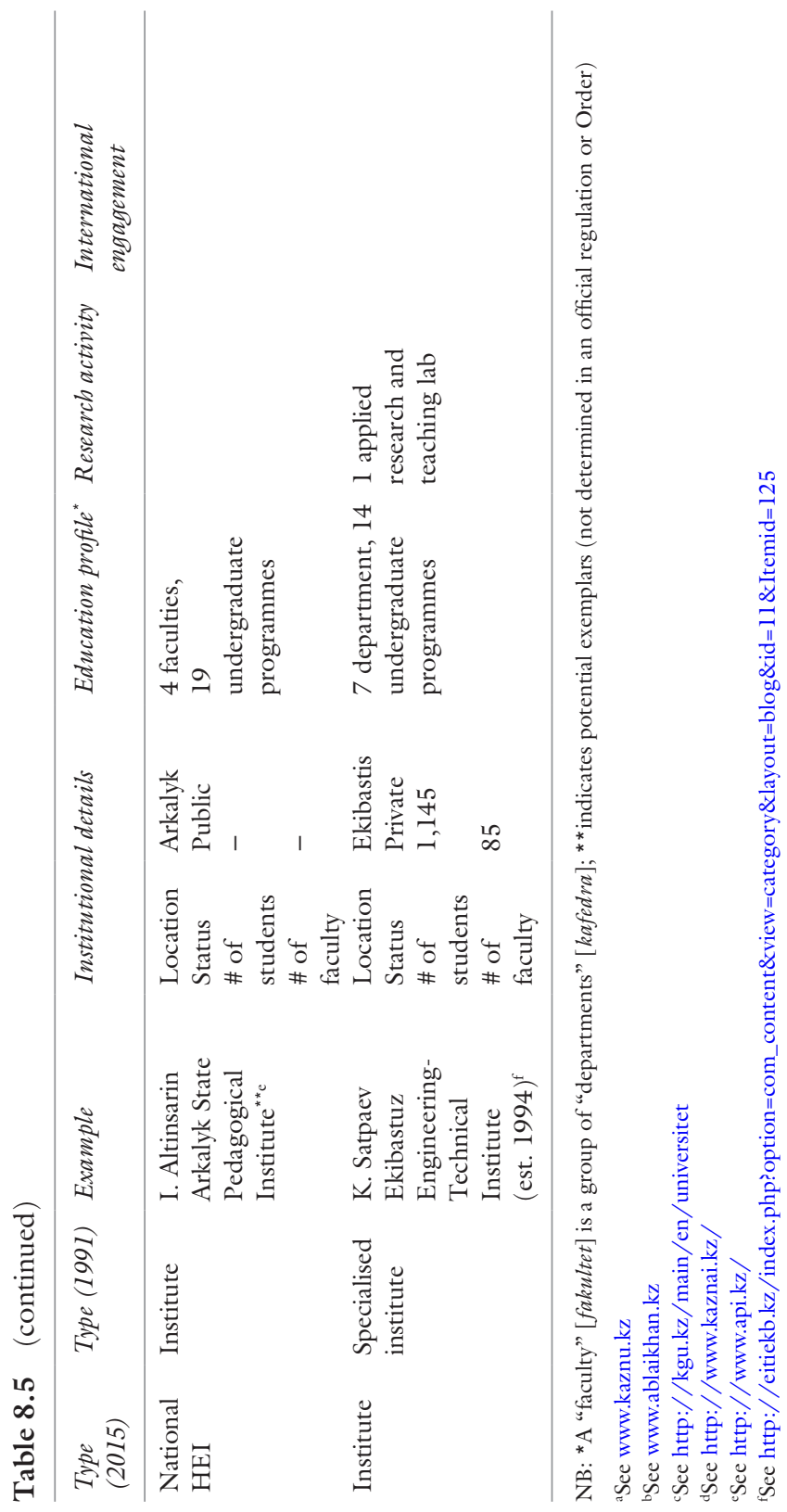




\section{CONCLUSION}

While joining the BP should lead to greater convergence across the EHEA, Kazakhstani HE has been embedded in a dynamic sociopolitical cultural context. For example, because the birth rate had declined in the 1990s (Fig. 8.1), HE enrolment is expected to decline from 2011 until around 2025. According to OECD (2007), the number of university-aged young people is expected to fall from 180,000 (2010) to below 120,000 (2025) - a 33\% decline over 15 years. Even with the MoES's efforts to close for-profit diploma mill universities between 2001 and 2015, Kazakhstan's demographic drop-off has had serious implications for faculty and staffing at the remaining 126 HEIs, since the majority of Kazakhstani HEIs are private and since all institutions are expected to be financially autonomous by 2020 .

From a systemic perspective, the Kazakhstani government has begun implementing many of the Bologna action points since joining the EHEA in 2010. Most notably, it has done the following: developed a necessary legal infrastructure; mapping out governmental and national-level organisational charts; and an array of procedural and substantive university autonomy and reform policies. But despite the plethora of HE reforms proposals and initiatives, there are a number of broad ranging challenges that the MoES continues to face, as Kazakhstan continues to navigate its way through its radical HE reform agenda (Heynemann 2010). For example, the "proliferation of actions, the plethora of agencies and committees and the frequent changes in the related regulations and processes are confusing and overburdening HE stakeholders" (OECD 2007, 117-118). This "proliferation of actions" and constant change are evident even in the way the MoES has been articulating its vision for an HE institutional infrastructure as seen in the MoES different organisational taxonomies presented in Tables 8.4 and 8.5.

Shifts in Kazakhstan's language policies also continue to change the linguistic context in which education is taking place. In AY1990-91, there was a greater percentage of students studying in Russian as compared to Kazakh. According to MoES $(2014,2015)$, there continues to be a shift in student enrolment from Russian to Kazakh-medium HEIs with a small, but growing number of enrollees in English-medium HEIs (2.6\%) in AY2014-15 (MoES 2015).

What remains the most idiosyncratic element of Kazakhstani HE is the role of the government in making decisions regarding $\mathrm{HE}$ with little or no 
transparency. Despite the existence of education governance in the form of the MoES, moves toward greater transparency and (imminent) institutional autonomy, in actuality, Presidential Orders have been used to establish HEIs-L.I. Gumilyov Eurasian National University, KIMEP University and Nazarbayev University ${ }^{17}$ - and have led to institutional mergers, Atyrau Institute of Oil and Gas and, most recently, the merger of K.I. Satpaev National Technical University with Kazakh-British Technical University (a JSC university). ${ }^{18}$ The primacy of the government to make decisions in and across different sectors points to the reality that in many post-Soviet countries, despite the development of systems and infrastructure, it retains enough power to be able to establish (or dissolve) institutions, initiatives and policies with little or no stakeholder involvement or public debate.

In its first 15 years, the Kazakhstani government focused on establishing the framework for a new HE system-one that would be able to meet the needs of an emerging market economy, thereby pivoting away from the Soviet-style HE infrastructure which it inherited. It has laid the building blocks for its development through the creation of its educationrelated regulatory structure (1990s) and embracing the BP agenda (2000s). Moreover, it has made strides toward creating a more competitive HE landscape by allowing the establishment of private HEIs, the privatisation of existing public HEIs, and creating a more vertically differentiated structure which ostensibly acts to delineate between "elite" and "mass" HE (Trow 1970). However, areas that will lead toward longlasting systemic and social change (e.g., curriculum content, programme structures and reporting and audit processes) still require significant amounts of reflection and change, with pre-independence HE organisational and institutional practices remaining entrenched. Moreover, because there has long been a lack of substantive stakeholder involvement in the HE reform process, there has been a lack of incentive to supporting reform implementation processes meaningfully, as evidenced by the disengagement from the reform process of both external stakeholders (business and civil society organisations) and internal stakeholders (faculty, lower- to mid-level administrators and students).

All this has been further problematised by the global economic crisis since 2009 , particularly because of the recent downward trend in prices of oil and other natural resources, and the continued devaluation of the Kazakhstani tenge, following the footsteps of the Russian ruble. This has, inevitably, shifted government into austerity mode-cutting public funding for what it deems to be non-essential and non-time sensitive educa- 
tional reforms, notably, the delay of implementing twelfth grade education on a larger scale, which has long-run implications for HE reform.

While signing up for the Bologna Process has somewhat clarified the HE vision, its implementation will test the resolve of government to persevere with the post-Soviet reform package. In this sense, Kazakhstan is, itself, a twenty-first century experiment in education reform (Kucera 2014), a process that is taking place in the context of both the geopolitical uncertainties and vulnerabilities in the Central Asia region and the transitional nature of the Kazakhstani economic, social and political environments.

In sum, the legacy of the Soviet Union in Kazakhstan is ambiguous. While there have been departures in terms of institutional types and education financing, its pedagogical legacy (approaches to teaching, learning and programme content) and administrative legacy (approaches to institutional reporting and accountability) remain. Continued change requires the MoES to continue its current trajectory of trying to aligning its $\mathrm{HE}$ agenda with the BP in order to continue innovating and preparing young people for work in the twenty-first century.

This chapter focused on the horizontal diversification, vertical differentiation and inter-organisational relationships among Kazakhstani HEIs. It is clear that, systemically, there have been significant departures from the Soviet-era institutions. But meeting future challenges cannot be done by one arm of the government in isolation; rather, it requires collaboration from all levels of governance and from the broad spectrum of HE stakeholders. It is in this area that we argue the lasting imprint of the Soviet legacy is more clearly evident, for example, the intra-institutional operational policies (e.g., student admissions) and the day-to-day practices within different HEIs. Thus, future research on intra-institutional reform could elucidate how transformation is experienced, interpreted and implemented at the local level and would provide a clearer picture regarding sustainable, meaningful and long-lasting transformation.

\section{Notes}

1. A number of schools and faculties were evacuated to the Kazakh SSR after World War II, along with many highly qualified faculty members due to political reasons.

2. Karaganda Pedagogical Institute became the second university in the Kazakh SSR, Karaganda State University in 1972 (http://www.euni.de/ 
tools/jobpopup.php?lang=en\&option=showJobs\&jobid=16693\&jobtyp= 7 \&university $=$ Buketov + Karaganda + State + University \& country $=$ KZ\& sid $=61473$ ).

3. It should be noted that many institutes conducted applied research for specific industries, for example, the Mining Institute (Institut Gordnogo Dela), under the auspices of the Academy of Sciences.

4. See http://www.constitution.kz

5. The move toward privileging the Kazakh language started before 1991the Soviet 1989 Law "On Language" established Kazakh as the state language of the Kazakh SSR. This law was passed when 62\% of Kazakhstan's ethnic Kazakh population indicated they fluently spoke Russian (Smagulova 2008).

6. See http://online.zakon.kz/Document/?doc_id=1001895

7. The exceptions were private institutes that were established by Presidential Order (1991), like the Kazakhstan Institute of Management, Economics and Research (KIMEP University since 2011) in Almaty.

8. See http://online.zakon.kz/Document/?doc_id=1018504

9. In the Kazakhstani education system, upper secondary includes grades 10 and 11 .

10. There has been on-going discussion about cancelling both exams and replacing them with a more comprehensive and rigorous university entrance exam. In 2013, the MoES announced that the UNT would be cancelled by 2015 (Lee 2013). However, at the time this chapter was written, the MoES had yet to provide an alternative university entrance exam and so, the UNT and CT tests were still being administered.

11. A number of Kazakhstani universities have begun implementing the MoES guidelines on ECTS. However, at the degree level, the MoES is struggling to harmonise the ECTS learning-hour with its own teaching-hour credit system without diminishing its student workload requirements for graduation (Dixon and Soltys 2013).

12. The Bolashak scholarship programme was a governmental programme that was instituted in 1994 and selects high-achieving Kazakhstani students to study abroad at top universities on the condition that they would come back and work in-country for a minimum of 5 years to offset brain drain.

13. Currently, all public HEI rectors continue to be political appointees.

14. See http://www.edu.gov.kz/ru/analytics

15. Additionally, all HEIs are still currently subject to regular licensing and attestation inspections, which are under the MoES's purview.

16. See http://online.zakon.kz/Document/?doc_id=30914968

17. See http://online.zakon.kz/Document/?doc_id $=30914968$

18. See https://www.interfax.kz/index.php?lang=eng\&int_id=10\&news_ id $=8961$ 


\section{REFERENCES}

Agency of Statistics of the Republic of Kazakhstan. 2013. Kazakhstan in Figures. http://www.eng.stat.kz

Aitzhanova, A., S. Katsu, J.F. Linn, and V. Yezhov, eds. 2014. Kazakhstan 2050. Toward a Modern Society for All. Oxford: Oxford University Press.

Asian Development Bank. n.d. Kazakhstan: Economy. http://www.adb.org/ countries/kazakhstan/economy

Brunner, J.J., and A. Tillett. n.d. Higher Education in Central Asia. The Challenges of Modernization. Washington, DC: World Bank.

Dixon, J., and D. Soltys, eds. 2013. A Handbook to Understanding the Bologna Process for Kazakbstani Higher Education Administrators. Almaty: Akadem Press.

Dzholdasbekov, U., and E. Kuznetsov. 1975. Kazakh State University and Higher Education in the Kazakh SSR. Alma-Ata: Kirov Kazakh National University.

European Commission [EC]. 2010. Higher Education in Kazakhstan. http:// eacea.ec.europa.eu/tempus/participating_countries/reviews/kazakhstan_ review_of_higher_education.pdf

Froumin, I., Y. Kouzminov, and D. Semyonov. 2014. Institutional Diversity in Russian Higher Education: Revolutions and Evolution. European Journal of Higher Education 2014: 1-26. doi:10.1080/21568235.2014.91653.

Heynemann, S.P. 2010. A Comment on the Changes in Higher Education in the Post-Soviet Union. European Education 42 (1): 76-87. doi:10.4934/ EUE1056-4934420104.

Heynemann, S.P., K.H. Anderson, and N. Nuraliyeva. 2007. The Cost of Corruption in Higher Education. Comparative Education Review 52 (1): 1-25. http://www.jstor.org/stable/10.1086/524367

Kazakhstani Ministry of Economics. 2015. Statistics of the Kazakhstani Ministry of Economics. http://stat.gov.kz/faces/wcnav_externalId/homeNumbersEducation?_afrLoop=19040397582307102 \#\%40\%3 F_ afrLoop\%3D19040397582307102\%26_adf.ctrl-state\%3D3v2o6ed7c_58

Kazakhstani Ministry of Education and Science [MoES]. 2010. The State Program of Education Development in the Republic of Kazakbstan for 2011-2020. Astana: MoES.

. 2014. Statistics of the Kazakhstani Education System. 2014. Astana: MoES. http://www.edu.gov.kz

-2015. Statistics of the Kazakhstani Education System. 2015. Astana: MoES. http://www.edu.gov.kz

Kazinform. 2010. Kazakhstan Joined the Bologna Process at Sitting of Bologna Ministerial Forum. Kazinform, March 12. http://www.inform.kz/eng/ article/2247114 
Kucera, J. 2014. Can a Homegrown University in Authoritarian Kazakhstan Incubate Reform? Al Jazeera, June 20. http://america.aljazeera.com/articles/2014/6/20/kazakhstan-s-audaciousnazarbayevuniversity.html

Kyzykeyeva, A., and A. Oskolkova. 2011. Historical Aspects of Higher Education in the Republic of Kazakhstan. The Kazakb-American Free University Academic Journal 3(2011). http://www.kafu-academic-journal.info/journal/3/5l/

Lee, D. 2013. Unified National Testing to be Replaced by Two Different Tests by 2015. Astana Times, September 23. http://www.astanatimes.com/2013/09/ unified-national-testing-to-be-replaced-by-two-different-tests-by-2015/

Moskva-Finansy i Statistika Razdel [Moscow Finance and Statistics Unit]. 1989. Narodniy Obrazovaniy i Kultura $v$ USSR [Education and Culture in the USSR], 202. Moscow: Moscow Finance and Statistics Union.

National Tempus Office. 2012. Higher Education in Kazakbstan. Brussels: European Union.

Nauchno Isledovatelskii Institut Vishego Obrazavaniya [NIIVO][Scientific Institute of Higher Education Research]. 1992. Universitet Rossii [Russia's Universities]. Spravochnik. Moscow: Nauchno Isledovatelskii Institut Vishego Obrazavaniya.

Organisation of Economic Co-operation and Development (OECD). 2007. Higher Education in Kazakhstan. Paris: OECD Publishing.

Piven, G., and I. Pak. 2006. Higher Education in Kazakhstan and the Bologna Process. Russian Education and Society 2006: 82-91. http://www.international.ac.uk/resources/14325144ut378r7g.pdf

Poletaev, D., and B. Rakisheva. 2011. Educational Migration from Kazakhstan to Russia as an Aspect of Strategic Cooperation Within the Customs Union. In Eurasian Integration-Historical and Social Aspects, 198-219. Moscow: Eurasian Development Bank.

Pomfret, R. 2014. Kazakhstan's Progress Since Independence. In Kazakbstan 2050. Toward a Modern Society for All, ed. A. Aitzhanova, S. Katsu, J.F. Linn, and V. Yezhov, 15-35. Oxford: Oxford University Press.

Rudista, N. 2004. Innovative Transformations of Higher Education in Far and Close Abroad Countries. Tyumen.

Rumyantseva, N.L. 2005. Taxonomy of Corruption in Higher Education. Peabody Journal of Education 80(1): 81-92. http://www.jstor.org/stable/1493336

Sarinzhipov, A. 2013. Opportunities for Faculty to Influence Academic Matters at Kazakh National University and Eurasian National University. Unpublished Doctoral Dissertation, University of Pennsylvania, Philadelphia.

Silova, I. 2011. Higher Education Reforms and Global Geopolitics: Shifting Cores and Peripheries in Russia, the Baltics, and Central Asia. Russian Analytical Digest, 97 (May 30, 2011). http://www.css.ethz.ch/publications/pdfs/RAD97.pdf 
Silova, I., and G. Steiner-Khamsi, eds. 2008. How NGOS React. Globalization and Education Reform in the Caucasus, Central Asia, and Mongolia. Bloomfield: Kumarian Press.

Smagulova, J. 2008. Language Policies of Kazakhization and Their Influence on Language Attitudes and Use. International Journal of Bilingual Education and Bilingualism 11 (3-4): 440-475.

Soltys, D. 2014. Similarities, Divergence, and Incapacity in the Bologna Process Reform Implementation by the Former-Socialist Countries: The Self-Defeat of State Regulations. Comparative Education 51 (2): 179-195. doi:10.1080/03 050068.2014.957908.

Sulima, S. 2008. Quality and Effectiveness of the Higher Education System in Kazakhstan During the 'Pre-reform Period.' Vestnik KASU 4. http://www. vestnik-kafu.info/journal/16/604/

Teichler, U. 1988. Changing Patterns of Higher Education Systems. London: Jessica Kingsley.

Thomson. n.d. Web of Science Home Page. www.isiwebofknowledge.com

Trow, M. 1970. Reflections on the Transition from Mass to Universal Higher Education. Daedalus 90 (1): 1-42.

UNESCO Institute of Statistics (UIS). n.d. Country Profiles. Kazakhstan. http:// www.uis.unesco.org/DataCentre/Pages/country-profile.aspx?code=KAZ\&re gioncode $=40505$

Yakavets, N. 2014. Educational reform in Kazakhstan: The First Decade of Independence. In Educational Reform and Internationalisation. The Case of School Reform in Kazakhstan, ed. D. Bridges, 1-27. Cambridge: Cambridge University Press.

Zhakenov, G. n.d. Kazakbstan National Report on Higher Education System Development. www.unesco.kz/education/he/kazakh/kazakh_eng.htm

Elise S. Ahn was an Assistant Professor at KIMEP University, Almaty, Kazakhstan, where she also worked as the Graduate Program Administrator in KIMEP's Language Center. Currently, she is the director of the Office of the International Projects at the University of Wisconsin-Madison (USA) and also an adjunct lecturer at Edgewood College's Doctorate of Education programme (Madison, WI). She has $\mathrm{a} \mathrm{PhD}$ in Educational Policy Studies from the Education Policy and Organization Leadership Department at the University of Illinois at UrbanaChampaign (USA) with a concentration in Comparative and International Education and a specialisation in Programme Evaluation. She has been awarded a number of awards, including a Fulbright-Schuman award to the European Union (2006-07). She co-edited a recently published book, Language Change in Central Asia (2016, Mouton de Gruyter), and has a number of forthcoming articles on issues related to emergent education stratification in post-Soviet Kazakhstan. 
John Dixon B Econ, M Econ, PhD, FAcSS, is a Professor of Public Policy and Public Administration at the Middle East Technical University in Ankara, Turkey. From 2009 to 2014, he was the Distinguished Professor of Public Policy and Administration at KIMEP University, where he was Dean of the College of Social Sciences (2009-12) and of the Bang College of Business (2013-14). He has held senior academic appointments in the UK (1997-2008), Hong Kong (1993-97) and Australia (1981-92). He is a fellow of the British Academy of the Social Sciences, and an honorary life member of the American Phi Beta Delta Honor Society for International Scholars.

Larissa Chekmareva is a $\mathrm{PhD}$ student in international education (University of Massachusetts, USA). She has served in the positions of the Deputy to the President, Dean for Enrollment Management and Registrar at KIMEP University (2000-14, Almaty, Kazakhstan). Her education consulting experience with UNESCO, UNICEF, World Bank, National Ministries of Education in Central Asia and so on include projects related to the quality of education, student assessment, international accreditation, academic credit system, Bologna Process, enrolment management and student information systems.

Open Access This chapter is distributed under the terms of the Creative Commons Attribution 4.0 International License (http://creativecommons.org/licenses/ by $/ 4.0 /$ ), which permits use, duplication, adaptation, distribution and reproduction in any medium or format, as long as you give appropriate credit to the original author(s) and the source, provide a link to the Creative Commons license and indicate if changes were made.

The images or other third party material in this chapter are included in the chapter's Creative Commons license, unless indicated otherwise in a credit line to the material. If material is not included in the chapter's Creative Commons license and your intended use is not permitted by statutory regulation or exceeds the permitted use, you will need to obtain permission directly from the copyright holder.

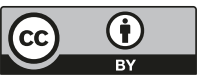

